\title{
Hour Times Nanogram per Milliliter per Milligram per Kilogram
}

National Cancer Institute

\section{Source}

National Cancer Institute. Hour Times Nanogram per Milliliter per Milligram per Kilogram.

NCI Thesaurus. Code C85628.

Hours times nanograms per milliliter per milligram per kilogram. 